Acta Regionalia et Environmentalica 1

Nitra, Slovaca Universitas Agriculturae Nitriae, 2018, pp. 10-14

\title{
THE CONTROVERSIAL NATURE OF WORKFARE PROGRAMMES
}

\author{
Imola Cseh PAPP*, Erika VARGA, Zoltán SZIRA, László HAJÓS \\ Szent István University, Gödöllő, Hungary
}

\begin{abstract}
According to the OECD, active employment policies include all social expenditure that are directed at improving the chances of finding a job and income generation (except education). Active labour market policies are around to assist in enhancing labour market flexibility at the times of economic changes. Their key components are the so-called activation strategies that act as typical prerequisites of benefitting from unemployment security/support systems in every EU country. The workfare concept lies behind the public work programmes. There are serious professional debates whether public work can primarily be seen as a 'compulsion and work test' or, rather, as an opportunity of entering the primary labour market. The available efficiency analyses unanimously state that public work forms have the biggest role in testing willingness to work and the obligatory nature is the strongest of all active labour market policies. Research also indicates that public work reintegrates only few people back to the primary labour market and the majority are restrained from seeking a job and other income generating activities. There are several reasons for and against public work and opinions differ. The paper summarises the benefits and drawbacks on the basis of international and Hungarian analyses.
\end{abstract}

Keywords: labour market policy, poverty, public work, unemployment, welfare programme

Public work has always come to the foreground when the former economic and employment forms have undergone some changes as at that time the labour market equilibrium could not be kept so there was scarcity of income and the intervention of a central power was inevitable. Public work is such an active instrument that can sell well politically. On the one hand, it has a moral base easy to identify with, and its impact can rapidly be felt, on the other hand. At the same time, however, public work programmes are debated and have a controversial nature: they are rather expensive and their use and results are uncertain, especially in the long run.

\section{Material and methods}

The objective of our paper is to give a detailed overview of evaluating programmes that are in the centre of heated political debates primarily on the basis of international literature.

As most data in social sciences are intangible, i.e. human actions and views, products that are worth examining, exact hypotheses could not be formulated in our exploratory research so an abductee approach was applied.

Reconstructing past events is based on abduction as we can guess events by concluding on the basis of their consequences and current impacts. The statements at the end are thought awakening but we hope they can contribute to the everyday and scientific debate on public work programmes.

\section{Results and discussion}

\section{The ideology}

Public work stands at the intersection of two ideologies. Based on the classical approach it is regarded as a sociopolitical instrument while according to the neoconservative or neoliberal approach it approaches criminal policy in a sense that the state enforces the right lifestyle (Szabó, 2013).

Several examples prove that state or local governmental investments are realised within the framework of public work. In such cases public work is not seen as a labour market policy, rather, it is an instrument to reach some state or community goals that can also serve as an employment policy, in addition. The American New Deal programme was born to address the Great Depression of 1929-1933. Its objective was to create jobs to the masses of unemployed and reinvigorate economic development. The state assisted in alleviating the graveness of the crisis by generating additional demand and realising infrastructural investments that provide the private sector, the enterprises and employees alike with income (Smith, 2006).

In Europe in the 2000's public work is labour forced by the state. If one is unable to find a job after benefitting from the contributions in the form of unemployment benefit, they will get a slight amount lower than the former one as benefit on the one hand, and also they have to undertake the job offered by the state, on the other hand (Csoba, 2010). Only 10 percent of the participants of public 
work programmes are channelled back to the legal labour market while this ratio is twice this amount in the case of those who have not participated in such programmes. The systematic way of life demanded by labour, and the hours of the day spent on work are really important parts in preserving mental and physical capacities but it is dubious whether this compulsion can neutralise the positive impacts (Szabó, 2013).

The term 'workfare' currently used comes from the Republican James Charles Evers from 1968 as a coinage of "work" and "welfare" and became widespread after President Nixon's 1969 August speech on television. The main point is that there are certain prerequisites of benefitting from state welfare services such as trainings, rehabilitation and work experience as well as unpaid and low-paying jobs. Most frequently it means that the unemployed are reintegrated into the world of labour, in certain positions and the welfare payments are gradually reduced or stopped for them. There are two explanations behind: the tax paying citizens can feel that they can obtain higher value in exchange for their contribution to the welfare system when they experience the work performed by those living on the dole. The most important objective is to organise a useful type of job for those between jobs that can socially be accepted and creates a new value. On the other hand, the unemployed can gain work experience in corporate life (Smith, 2006). However, if the unemployed are reintegrated into the world of work, their income will generate taxes.

The workfare instruments are directed at reducing the number of those on the dole in two ways. On the one hand, they select and exclude those who are working (and not entitled to the benefit) or who are not seeking a job (as it is the prerequisite of the benefit). The filtering impact of the programme can prevail in attracting those who are really in need and keep off the wealthier, which can reduce the administrative cost of the government. The principle of 'little alternatives' prevails in the salary and work conditions, as well. Public work should not be more attractive from any aspect than the open labour market opportunities. On the other hand, individuals are pushed into situations where human capital can be improved and chances are higher for finding a job. Workfare includes such different programmes and approaches that are based on the different combinations of these two mechanisms (Heikkilä et al., 2002; Ko and Cho, 2017).

\section{The developed and the developing countries}

The concept of workfare lies behind the public work programmes. These programmes have become widespread in the developed countries mainly since the economic and financial crisis. Workfare principle prevails in the USA (Temporary Assistance for Needy Families; Work Experience Programme; Wisconsin Works; Community Jobs), Australia (Work for Dole) and Canada (Canada Health and Social Transfer; Ontario Works) (Marston and McDonald, 2008). The groups targeted are usually special social groups so these programmes frequently include re-employability (combined with trainings) and occasionally serve welfare functions (such as the programme of South Africa', France, China, South Korea, Latvia and Portugal) (Kim and Zurlo, 2007; Melo, 2009; Robbins, 2015; Bertrand, 2017).

In the developed countries they are only moderately used as they are expensive and other active labour market policies have proved to be more effective (Alegre, 2017) primarily due to their substitution and crowding out effects. Most typically, public work programmes are employed in the developed countries only in the short term as a reaction to a short term economic shock or in case of high unemployment rate. The developed countries have a well-functioning and fairly flexible labour market so public work programmes are usually launched to reintegrate the unemployed to the world of work (Beaudry, 2002). When launching public work programmes it is a must to consider that they should not impede the primary labour market, rather, they should support it (Eardley et al., 1996; Grover and Stewart, 1999; Bergin, 2018; Norton, 2018).

Public work is getting more and more widespread in the developing world to fight poverty, and with the objective of guaranteed employment or transition leading to selfemployment such as in Argentina, Ethiopia, India (Adimassu et al., 2015; Shah and Steinberg, 2015; Ismail, 2016; Rosas and Sabarwal, 2016; Mourelo and Escudero, 2017; Karimi, 2018). The National Rural Employment Guarantee Act (NREGA) of India offers 100 paid working days to those entitled instead of the unemployment benefit known in the western model. The Mahatma Gandhi National Rural Employment Guarantee Scheme (MGNREGS) programme available for 54 million households also contributes to reducing poverty by raising agricultural wages in the market where most people are affected by the programme as an indirect effect. Argentina (Programa Intensivo; Trabao, Programa Trabajar; Programa Jefes de Hogar) has been affected since its grave economic situation (1992) where projects to improve agricultural enterprises (such as irrigation) are supported or direct agricultural production is another example due to community gardens. In Ethiopia implementing the irrigation system was realised within the framework of small scale farms managed by well discernible social groups, i.e. women at a disadvantaged situation (Fachelli et al., 2004; Ronconi et al., 2006; Ravi and Engler, 2015).

The most important difference between the developed and the developing countries is that in the latter ones the public work programmes are aimed at managing structural, long lasting problems and not temporary economic shocks and typically they are linked to developing infrastructure. In the developing countries the most underdeveloped settlements are targeted, which is a kind of selection, and the public work wages are below the average market wages of the poor. Public work programmes offer few opportunities of breaking out for those in a very disadvantaged situation (Koós, 2016).

In Hungary it is also typical that public work is the only form of connection to the formal world of labour in the

1 The labour market of South Africa has significantly been transformed since 1994. Several laws and labour regulations were made since the mid-1990's to eradicate the labour market injustices and inequalities of the past and improve the general conditions of employment. 
peripheral rural areas. For those living there this is the much desired source of living as their poverty is not temporary, but it is a lifestyle. In this way, several jobs are created in rural areas, especially in agriculture, that do not require much expertise. Participation in agricultural programmes means a salary which is lower than the minimum wage but is a fixed source so it has become an alternative for seasonal employment and commuting to work (Uszkai, 2014; Koós, 2016; Váradi, 2016; Kovács, 2018). The broad acceptance of workfare can be due to the fact that for the local governments it provides cheap labour and sources that generate significant local developments. Within the framework of public work programmes there have been a lot of good practices to share (e.g. the streets of Tiszakécske, wood products of Csávoly, jam specialities in Boldogasszonyfa) that are backed by local efforts (László, 2016) that had been in existence previously, though without enough sources.

The employment capacities of the primary labour market are either totally absent or very limited. It is also well known that the participants of the workfare programmes as employees do not have the assets regarding qualification, social status, connections or work experience that would set productivity on the primary labour market as an example for them. The formal job opportunities have disappeared from the gypsy villages in the periphery of the country and the only source of income for those living here is family support, social transfer and participation in public work in addition to the very occasional odd job opportunities (Csoba, 2017; Virág, 2017). At the same time, however, for those not having a job for a long time there are no other employment and job opportunities. In an examination (Csehné, 2018) such opinions were voiced that do not debate the success of the programmes. Participants compare the positive and the negative experience of everyday work with their own ambitions and purposes and on the whole, they are satisfied. If the programme succeeds, it does not mean employment on the supported or open labour market, rather, it would result in decreasing the number of those living on the dole and justifying the fact that access to goods can only be granted through work (Koós, 2016; Váradi, 2016; Czibere and Molnár, 2017).

Researchers also draw attention to the negative aspects of the programme (Cseres-Gergely and Molnár, 2014) as it turned out that the number of those having spent a long time in the labour system without participating in any active labour market programme is extremely high. The analyses of the researchers point out that the chances for being pushed out of the system of public work are lower than those of other programmes and the more one has been involved in public work, the lower the chances of getting out of the system are. To date, public work will be transformed from its original function of being an active labour market policy that transforms temporary employment into an employment opportunity available for everybody in Hungary.

The situation analysis of the post socialist (Lissowska, 2017) and V4 countries (Sulich, 2016) concludes that public work previously considered as a temporary instrument provides job opportunities for the unskilled who have been unemployed for a long time. After the careful analysis of the current situation of the Visegrad group, it is difficult to envisage the dramatic decline of unemployment in the forthcoming years as these governments do not have the proper financial means to support the labour market. Some critical analysts forget about it and conclude that the primary objective is not the decrease of unemployment, rather, the increase of employment.

The public work programmes of the developing and developed countries have some things in common. Basically, they ensure short term employment for the unemployed and reduce poverty due to income transfers. However, a difference is that regional development is the objective for the developing countries while for the developed countries it is the improvement of employment that is more significant. It is also reflected in the fact that the developing countries are project based while the developed countries are characterised by mostly programme based approaches. In general, it is stated that public work programmes can function as the instruments of social network fighting against poverty if they are well targeted by ensuring temporary employment if they are directed at very disadvantaged regions or special labour market groups (Subbarao et al., 2013, Ninno et al., 2009; Zimmermann 2012; Siemiatycki, 2016; Martín-Antón et al., 2017; Bertrand, 2017). At the same time, however, experts also agree that this effect can only be felt rather in the short term when the wages of public work remain under the minimum wage (Datta and Chakrabarti, 2016). However, public work programmes cannot be regarded as active programmes that would increase the chances of employment and reintegration as they are rather expensive (Brown and Koettl, 2015; McKenzie, 2017).

\section{Pros and cons}

One of the greatest challenges of the $21^{\text {st }}$ century is unemployment, social exclusion and reducing regional differences. That is why it is necessary to think over the labour concept and work out new employment models. Workfare has become a dominant social welfare approach in many different cities of the world to tackle unemployment. The current welfare system provides such a high level of supplies that it prevents people from working.

Those who are for the concept of workfare state if a person has very recent work experience, the chances are higher for a better paid job for a longer term.

The critics of the workfare system highlight that there is no evidence whether participation in the programme would increase the chances of finding a new job. They state that the chances of the participants for finding a job are even worse as they can waste their precious time on such a programme that does not provide them with practical knowledge or skill appreciated by their future employer. The workfare strategy based on the old fashioned labour concept can contribute to the depreciation and marginalisation of the work performed by the disadvantaged groups.

The following arguments are for workfare type public work programmes (Besley and Coate, 1992; Kálmán, 2015):

- political popularity - Public work is such an active policy that can properly be communicated in politics partly due to its moral basics and its spectacular nature as it yields results quickly;

- widening infrastructure - Creating jobs from state funds serve public goods and infrastructure. Realising 
investments in infrastructure will result in income for the private sector, enterprises and employees alike;

- reducing poverty - The well targeted and closely monitored public work programmes in the developing countries are suitable for managing temporal poverty in micro regions even in longer terms. Public work wages are higher than the amount of benefits: they make life better, ease poverty and protect from final impoverishment;

- strengthening social cohesion - Occasional work can contribute to reducing exclusion;

- fighting against black work - Public work can ensure sources of legal income;

- regular work - The regular way of leading life, working days are really important parts of preserving mental and physical health. Due to public work everyone can make their living and take responsibility for managing their own lives.

Arguments against workfare type public work programmes include:

- segregation;

- performing demanding physical work - Most of the typical jobs in public work are physical that do not require any skilled labour;

- not providing useful work experience - Most tasks do not prepare and do not provide employees with work experience that would assist them in finding a job in the labour market;

- preventing job seeking - According to research public work reintegrates only a few people to the primary labour market and prevents most of them from finding a new job or other sources of income generation;

- crowding out effect - Subsidised companies can make advancement and gains over those not subsidised;

- "getting stuck" effect - Those concerned can be in a more disadvantaged situation because due to their participation in the programme their time spent on job seeking is reduced so they are in a vicious circle;

- budgetary substitution effect-The budgetary substitution effect on public expenditure can take effect if the too expensive or too long public work programme takes the sources away from other, possibly more effective pubic political programmes;

- dead weight loss can appear - A question can be raised whether the job concerned could have been created without public work subsidies;

- job distortion effect - Even the employees who could find a job in the primary labour market would rather find one in public work.

The most important objective of creating socially acceptable and useful jobs for the unemployed that create new values seems to be fulfilled. However, the idea according to which public work would decrease unemployment and reduce the number of those on the dole is only true if several impact studies are made on the work performed. According to generally accepted professional opinions the public work programmes cannot take the place of active labour market programmes that increase labour market chances and assist reintegration. In comparison with other active employment policy programmes (subsidising enterprises, wage subsidies, labour market trainings) the participants of public work have lower chances of finding a job, which can be explained by the components of the group (low level of education, higher participation in unemployment benefit). The members of the most disadvantaged group of dropouts who can hardly be motivated cannot be channelled to the open labour market at once with standard labour market policies. For those concerned the cooperation between the local labour, social and healthcare institutions is of vital importance.

\section{Summary and conclusions}

The paper tries to find an answer to the question of where exactly the objectives of public work could fit among the other employment policies, economic development and social political concepts. According to the available results public work can mean a solution only in certain cases and it raises as many questions as it answers. To sum up, the organisers do not expect public work to ensure supported or open labour market employment, rather, the reduction on the number of those on the dole and the acceptance of the principle that access to social goods can only be granted by performing work.

\section{References}

ADIMASSU, Z. - KESSLER, A. 2015. Impact of the productive safety net program on farmers' investments in sustainable land management in the Central Rift Valley of Ethiopia. In Environmental Development, vol. 16, 2015, pp. 54-62.

ALEGRE, J.G. 2017. The efficiency of active labour market policies in the European Union: Does it make sense increasing the bill? In Acta Oeconomica, vol. 67, 2017, no. 3, pp. 333-357.

BEAUDRY, R. 2002. Workfare and welfare: Britain's new deal. CCGES/ CCEAE Working papers series, 2002, no. 2

BERGIN, A.K. 2018. The labor market in Ireland, 2000-2016. IZA World of Labor, 2018.

BERTRAND, M. - CRÉPON, B. - MARGUERIE, A. - PREMAND, P. 2017. Contemporaneous and Post-Program Impacts of a Public Works Program. 2017, 57 p.

BESLEY, T. - COATE, S. 1992. Workfare versus welfare: Incentive arguments for work requirements in poverty-alleviation programs. In The American Economic Review, vol. 82, 1992, no. 1, pp. 249-261. BROWN, A.J. - KOETTL, J. 2015. Active labor market programsemployment gain or fiscal drain? In IZA Journal of Labor Economics, vol. 4, 2015, no. 1, 12 p.

CSEHNÉ PAPP, I. 2018. A közhasznú foglalkoztatottak föbb jellemzőinek változása 20 éves időtávban. Egy kistérségi kutatás eredményei. In Munkaügyi Szemle, vol. 61, 2018, no. 2, pp. 44-48.

CSERES-GERGELY, Zs. - MOLNÁR, Gy. 2014. Közmunka, segélyezés, elsődleges és másodlagos munkaerőpiac. In Társadalmi riport, TÁRKI, Budapest, 2014, pp. 204-225.

CSOBA, J. 2010. Segély helyett munka. In A közfoglalkoztatás formái és sajátosságai Szociológiai Szemle, vol. 20, 2010, no. 1, pp. 26-52.

CSOBA, J. 2017. A kertkultúra és a háztartásgazdaság szerepe a vidéki szegények társadalmi integrációjában - 25 éves a Szociális Földprogram. In Tér és Társadalom, vol. 31, 2017, no. 3, pp. 85-102.

CZIBERE, I. - MOLNÁR, E. 2017. Labour market perspectives of young women living in extreme poverty in closed rural space: the case of a Hungarian-Romanian cul-de-sac border village. Ager. In Revista de Estudios sobre Despoblación y Desarrollo Rural, 2017, no. 23, pp. 7-26. 
DATTA, P. - CHAKRABARTI, S. 2015. Gains from short-term public works: A review of performance of MGNREGA in Tripura. In The NEHU Journal, vol. 13, 2015, no. 1, pp. 57-77.

EARDLEY, T. - BRADSHAW, J. - DITCH, J. - GOUGH, I. - WHITEFORD, P. 1996. Social Assistance schemes in the OECD countries. In Synthesis report, DSS Research Report 46, London : HMSO, 1996.

FACHELLI, S. - RONCONI, L. - SANGUINETTI, J. 2004. Poverty and employability effects of workfare programs in Argentina. In Poverty and Economic Policy (PEP) Research Network : Call for Research Proposals, 2004, $24 \mathrm{p}$.

GROVER, C. - STEWART, J. 1999. Market workfare: Social Security, social regulation and competitiveness in the 1990s'. In Journal of Social Policy, vol. 28, 1999, no. 1, pp. 73-96.

HEIKKILA, M. - HVINDEN, B. - KAUTTO, M. - MARKLUND, S. - PLOUG, N. (Eds.). 2002. Nordic social policy: changing welfare states. Routledge, 2002, 324 p.

ISMAIL, M.A. 2016. Globalization and new international public works agreements in developing countries: an analytical perspective. Routledge, 2016, 316 p.

KÁLMÁN, J. 2015. A közfoglalkoztatási programok háttere és nemzetközi tapasztalatai. In Munkaerőpiaci tükör, MTA Közgazdaság-és Regionális Tudományi Kutatóközpont Közgazdaság-tudományi Intézet, Budapest, 2015, pp. 42-58.

KARIMI, Z. 2018. Public Works Programs as a Strong Means for Land and Water Conservation in Iran. In Full Employment and Social Justice. Chapter 5. Binzagr Institute for Sustainable Prosperity book series (BISP), 2018, pp. 109-138.

KIM, T.K. - ZURLO, K.A. 2007. Factors that influence workfare program participants: focusing on South Korea's Self-Sufficiency Program. In Int'I Soc. Work 50, 2007, 796 p.

$\mathrm{KO}, \mathrm{H}$. - CHO, H. 2017. Revisiting the effectiveness of the employment-oriented welfare state: Considering the quality of employment achievement. In Asian Social Work and Policy Review, vol. 11, 2017, no. 2, pp. 158-167.

KOÓS, B. 2016. Közfoglalkoztatás a mezőgazdaságban. In Tér és Társadalom, 2016, no. 3, pp. 40-62.

KOVÁCS, K. 2017. Managerial Challenges in Hungarian Agricultural Enterprises. In BRYLA, P. Managing Agricultural Enterprises. Expoing Profitability and Best Practice in Central Europe. Palgrave Macmillan, Cham. 2017, pp. 225-239.

LÁSZLÓ, Gy. 2016. A hátrányos helyzetűek foglalkoztatás nehézségei. In Opus et Educatio, vol. 3, 2016, no. 3, pp. 264-276.

LISSOWSKA, M. 2017. The financial crisis and changing labour markets in post-transition countries. In European Journal of Industrial Relations, vol. 23, 2017, no. 1, pp. 17-32.

MARSTON, G. - McDONALD, C. 2008. Feeling motivated yet? Longterm unemployed people's perspectives on the implementation of workfare in Australia. In Australian Journal of Social Issues, vol. 43, 2008, no. 2, pp. 255-269.

MARTÍN-ANTÓN, M. - NEGRO, V. - Del CAMPO, J. M. - LÓPEZGUTIÉRREZ, J.S. - Esteban, M.D. 2017. The Gigantism of Public Works in China in the Twenty-First Century. In Sustainability, vol. 9, 2017, no. 9, 14 p.

MCKENZIE, D. 2017. How effective are active labor market policies in developing countries? A critical review of recent evidence. In The World Bank Research Observer, vol. 32, 2017, no. 2, pp. 127-154.

MELO de, J.J. 2009. Public works policy in Portugal: a case study in unsustainability. Lusiada. In International Journal of Engineering and Industrial Management, vol. 1, 2009, pp. 193-208, pp. 195-208.
MOURELO, E.L. - ESCUDERO, V. 2016. Effectiveness of Active Labor Market Tools in Conditional Cash Transfers Programs: Evidence for Argentina. ILO Research Department - Geneva, Working Paper No. 11, 02.14.2, 2016, $27 \mathrm{p}$.

NINO, C.D. - SUBBARAO, K. - MILAZZO, A. 2009. How to Make Public Works Work : A review of the experiences (No. 48567). The World Bank, 2009, 93 p.

NORTON, T.R. 2018. Lessons Learned in Disaster Debris Management of the 2011 Great East Japan Earthquake and Tsunami. The 2011 Japan Earthquake and Tsunami: Reconstruction and Restoration, 2018, pp. 67-88.

RAVI, S. - ENGLER, M. 2015. Workfare as an effective way to fight poverty: The case of India's NREGS. In World Development, 2015, no. 67, pp. 57-71.

ROBBINS, B. 2015. FORUM: University of Edinburgh Postgraduate. In Journal of Culture \& the Arts, 2015, no. 21, 7 p.

RONCONI, L. - SANGUINETTI, J. - FACHELLI, O.S. 2006. Poverty and employability effects of workfare programs in Argentina. PMMA Working Paper No. 2006-14, 43 p.

ROSAS, N. - SABARWAL, Sh. 2016. Public Works as a Productive Safety Net in a Post-Conflict Setting: Evidence from a Randomized Evaluation in Sierra Leone. Policy Research Working Paper; No. 7580. Washington, DC : World Bank, (c) World Bank. License: CC BY 3.0 IGO, 2016, 33 p. https://openknowledge.worldbank.org/ handle/10986/23916

SHAH, M. - STEINBERG, B.M. 2015. Workfare and Human Capital Investment: Evidence from India. National Bureau of Economic Research - NBER Working Paper No. 21543, 2015, 37 p.

SIEMIATYCKI, M. 2016. Cycles in Megaproject Development. The Oxford Handbook of Megaproject Management, 2016, 39 p.

SMITH, J.S. 2006. Building New Deal Liberalism: The Political Economy of Public Works, 1933-1956. Cambridge : University Press, 2006, $283 \mathrm{p}$.

SUBBARAO, K. et al. 2013. Public Works as a Safety Net: Design, Evidence, and Implementation. Directions in development, human development. Washington DC : The World Bank, 2013, 430 p.

SULICH, A. 2016. Active labour market policy as a source of legitimacy for governments of Central Europe countries comparative analysis. In World Scientific News, 2016, no. 60, pp. 78-91.

SZABÓ, A. 2013. A közfoglalkoztatás, mint foglalkoztatápolitikai eszköz. In Nagyerdei Almanach, 2013, no. 2, pp. 149-161.

USZKAI, A. 2014. Innováció és oktatás az élhetőbb vidékért. In A Falu, vol. 29, 2014, no. 2, pp. 75-85.

VÁRADI, M. 2016. Értékteremtő közfoglalkoztatás periferikus vidéki terekben. In Esély, 2016, no. 1, pp. 30-56.

VIRÁG, T. 2017. A cigányfalu mint jelenség és értelmezési keret. In Replika, vol. 104, 2017, no. 4, pp. 45-62.

ZIMMERMANN, L. 2012. Labor market impacts of a large-scale public works program: Evidence from the Indian Employment Guarantee Scheme. In Forschungsinstitut zur Zukunft der Arbeit - Institute for the Study of Labor, IZA Discussion Paper No. 6858, 2012, 54 p. 